\title{
The Impact of Unconventional Monetary Policies on the Stocks of Bank Deposits: Evidence at an Aggregate Level in the Euro Area
}

\author{
Paolo Agnese ${ }^{1,2}$, Paolo Capuano ${ }^{1} \&$ Luca Secondi $^{3}$ \\ ${ }^{1}$ LUMSA University, Rome, Italy \\ 2 UNINETTUNO University, Rome, Italy \\ ${ }^{3}$ University of TUSCIA, Viterbo, Italy \\ Correspondence: Paolo Agnese, UNINETTUNO University, Rome, Italy.
}

Received: November 2, 2020

Accepted: December 4, 2020

Online Published: December 15, 2020

doi:10.5430/ijfr.v11n6p270

URL: https://doi.org/10.5430/ijfr.v11n6p270

\begin{abstract}
Due to the severity and persistence of the global financial crisis started in 2007, central banks all over the world have adopted Unconventional Monetary Policies (UMPs), including negative policy rates, longer-term refinancing operations and large-scale purchases of financial assets. In this study, by referring to a time-series regression analysis with Newey-West correction, we evaluate the impact of UMPs implemented by the Eurosystem over the period 2008-2019 on the stocks of euro area banks' deposit from households and non-financial corporations. The analysis of the effects of UMPs on the stocks of banks' deposit represents a particularly innovative aspect of this research, where most of the scientific literature focuses on deposit interest rates. Our results suggest that the UMPs conducted by the Eurosystem have had a significant positive impact on euro area bank deposits, with particular reference to the relationship between Longer-term refinancing operations and Household overnight deposits, as well as between Securities held for monetary policy purposes and deposits from Households (total deposits) and from Corporates (overnight deposits).
\end{abstract}

Keywords: Eurosystem, unconventional monetary policies, retail deposits, Euro area banks

JEL codes: E52, E58, G01, G21

\section{Introduction}

The seriousness and persistence of the global financial crisis started in 2007 have required Unconventional Monetary Policies (UMPs) taken by central banks around the world, in order to contain risks of low inflation or deflation and to counteract the slowdown in economic activity. The UMPs refer, in general terms, to all the new or innovative instruments of monetary policy, such as negative interest rates, longer-term refinancing operations, large-scale purchases of financial assets and forward guidance (for a taxonomy see, for instance: BIS, 2019; Borio and Zabai, 2016; Stone et al., 2011). Despite a common international financial crisis, the various central banks have adopted different UMPs strategies based on their respective mandates and considering the role of credit institutions in financing the economy.

Several authors studied the impact of UMPs on the pass-through of negative interest rate policy (NIRP) to deposit rates (Altavilla et al., 2019; Bech and Malkhozov, 2016; Brei et al., 2019; Claessens et al., 2017; Demiralp et al., 2019; ECB, 2016; Eisenschmidt and Smets, 2018; Heider et al., 2018). Our paper, however, explores the effects of these policies on the volumes of retail deposits: this aspect is little explored by the reference literature. In detail, by means of time-series regression analysis accounting for the existence of autocorrelation and heteroskedasticity through the Newey-West estimator, we analyze the impact of UMPs implemented by the Eurosystem over the period 2008-2019 on the stocks of bank deposits (from households and from non-financial corporations) within the euro area (Note 1).

The remainder of the paper is organized as follows. Section 2 presents a literature review on the concerned topic. Section 3 describes the methodology adopted in the analysis and presents the empirical results. Lastly, Section 4 summarizes the paper and proposes some conclusions. 


\section{Literature Review}

As it is known, banks seek funding from retail and wholesale sources. Retail funding consists of deposits from non-financial private sector, predominantly from households. Wholesale funds, on the other hand, consist broadly of funding from private markets. With reference to the short-term, wholesale sources include interbank liabilities and other short-term debt, most notably repurchase agreements (repos), commercial paper and certificates of deposit. For longer maturities, banks issue medium-term notes and bonds. In addition, banks receive liquidity from monetary authorities. Capital is also part of bank funding (ECB, 2016; Van Rixtel and Gasperini, 2013).

Retail deposits are generally the largest component of bank funding and tend to be less volatile than wholesale sources. This is for a variety of reasons, including transaction and switching costs and greater predictability based on the law of large numbers. In addition, retail deposits are "sluggish", insensitive to risks and more "sticky" than wholesale liabilities. Indeed, they are less subject to withdrawals related to uncertainty, in view of the fact that they are normally insured up to a certain amount by guarantee schemes (Note 2). Their withdrawals are determined, above all, by the liquidity needs of depositors (ECB, 2016; Huang and Ratnovski, 2011; Van Rixtel and Gasperini, 2013; Song and Thakor, 2007). On the contrary, wholesale funds are more sophisticated, because their holders are usually more interested in bank solidity (Huang and Ratnovski, 2011).

With reference to the impact of the UMPs on bank intermediation activity, several studies analyze the pass-through of NIRP to deposit rates. In normal times and according to the standard interest rate channel, changes in official monetary policy rates are transmitted to deposit and loan rates through the banking system. Regarding deposit rates, they are reduced when the monetary policy rate is lowered. However, when the policy rate turns negative, banks are reluctant to charge negative rates to a portion of their deposits (Bech and Malkhozov, 2016; Brei et al., 2019; Claessens et al., 2017; ECB, 2016; Eisenschmidt and Smets, 2018; Heider et al., 2018). Demiralp et al. (2019) argue the existence of a zero lower bound (ZLB) for retail deposits, although there are some banks that apply negative rates to households, and more widely, to non-financial companies deposits. Eisenschmidt and Smets (2018) find that the ZLB seems to exist only for interest rates on deposits held by households. Other funding sources, such as interbank liabilities and deposits held by non-financial corporations have fallen into negative territory, following the trend of monetary policy rates. Altavilla et al. (2019) also find that the ZLB may exist for household deposits and not for other counterparties. Furthermore, the same authors show that banks do not register a contraction in deposits when they charge negative interest rates. On the contrary, when the ZLB has been hit, demand for liquidity and safe assets grows. However, the ZLB for retail deposits means that a part of banks' funding can't be re-priced further once this threshold is reached, with the consequence of repercussions on the standard transmission mechanism (Demiralp et al., 2019).

Banks are reluctant to charge negative rates on their household deposits for a variety of reasons. One reason is motivated by the concern that negative deposit rates might lead to substantial withdrawals, as when deposits offer a negative nominal return they become inferior to cash (Bech and Malkhozov, 2016; Demiralp et al., 2019; Heider et al., 2018). Being typically of small amounts, household deposits may be easily withdrawn and held as cash. This unlike corporations, which cannot as easily conduct their process payments without deposits (Altavilla et al., 2019; Eisenschmidt and Smets, 2018). The fact that banks are reluctant to pass-on negative rates to part of the deposits might also reflect commercial policies, since retail depositors are likely to be less averse to an increase in commissions than to a negative deposit rate (ECB, 2016). Furthermore, banks fear losing the franchise value derived from cross-selling products, like consumer credit and mortgage. This franchise value is high enough to justify banks paying to increase the stocks of their deposits, with premiums between 1 and 2 percent (Claessens et al., 2017). Another reason why banks are reticent to lower retail deposit rates below zero is related to costs associated with switching to a different business or funding model (Demiralp et al., 2019). In addition, new liquidity regulations - in particular the Net Stable Funding Ratio (NSFR) regulation - have increased the value of household deposits as a funding source for banks (Eisenschmidt and Smets, 2018).

However, the literature that analyzes the deposit quantities is rather sparse. This study aims to enrich this literature, as it focuses on the impacts of UMPs implemented by the Eurosystem since 2008 on bank deposit stocks held by euro area households and non-financial corporations.

\section{Methodology and Empirical Results}

\subsection{Data Source}

The data are collected using "ECB Statistical Data Warehouse" as source, with monthly historical series over the period 2008-2019. In particular:

- with reference to the key ECB interest rates, we include in the analysis the main refinancing operations rate 
(these operations provide the bulk of liquidity to the banking system) and the deposit facility rate (banks can use this alternative to make overnight deposits with the Eurosystem). The analysis therefore does not also consider the marginal lending facility (these operations offers overnight credit to banks from the Eurosystem). Considering that the ECB's Governing Council takes monetary policy decisions every six weeks, we process these time series on a monthly basis;

- the main refinancing operations, the longer-term refinancing operations and the securities held for monetary policy purposes (large-scale purchases of financial assets) refer to the consolidated financial statement of the Eurosystem. The historical series of the securities held for monetary policy purposes are not available on a monthly basis. We then use the weekly data from these three variables as a source. To homogenize them with the other historical series, we process these data on a monthly basis, by calculating the median of the weekly observations;

- the stocks of the retail deposits considered are from euro area households and non-financial corporations (all currencies combined, denominated in euro, not seasonally adjusted, outstanding amounts at end of period) and refer to the banks' balance sheet. The analysis includes both overnight deposits and total deposits from households and non-financial corporations.

In this paper we analyze the data at an aggregate level, without distinguishing from country to country. Therefore, independent variables are considered at Eurosystem level, while dependent variables consider the data at euro area level.

\subsection{Variables of Model}

In this section we describe the variables of model. In particular, for purposes of the regression analysis, we distinguished variables into:

- dependent variables: stocks of bank deposits (overnight and total deposits) from euro area Households and non-financial Corporations;

- key independent variables: key ECB interest rates (Main refinancing operations rate and Deposit facility rate); Main refinancing operations; Longer-term refinancing operations; Securities held for monetary policy purposes.

\subsection{Model Selection and Specification}

Bearing in mind the aims of our research, we carried out a regression analysis by referring to the Newey-West estimator which properly considered the nature of our data and produced Heteroskedasticity and Autocorrelation Consistent (HAC) standard errors (Newey and West, 1987) and even recently applied for the analysis of banking and finance issues and the regression analysis on time series data (Ballis and Drakos, 2020; Ho and Lin, 2020; Narayan et al., 2020; Yahaya et al., 2020; Kladívko and Österholm, 2020). Indeed, the Newey-West (HAC) robust standard errors are consistent when the error term is heteroskedastic, autocorrelated, or both, as long as the regressors are stationary and ergodic. These robust standard errors are kin to White's heteroskedasticity-robust standard errors. Precisely they are identical to the White estimator with lag length zero (Hoechle, 2007) and enable to correct Ordinary Least Squares (OLS) standard errors to account for the presence of serial correlation (Stock and Watson, 2011).

We estimated four different regression models by considering each of the dependent variables listed in the previous section to be function of the same set of explicative variables, both considered in first-difference values due to the additive nature of the original values.

Without loss of generality, the generic regression model with HAC standard errors was specified as follows:

$$
Y_{t}^{\prime}=\beta_{0}+\sum_{k=1}^{K} \beta_{k} X_{k t}^{\prime}+\varepsilon_{t}
$$

where $Y_{t}^{\prime}=Y_{t}-Y_{t-1}$ indicates the outcome (dependent) variables identified as the first-difference (period-to-period change) and computed as the difference between the value of the dependent variables observed in period (year) $t$ and the correspondent value observed in the period (year) $t$ - 1 . The same computation and meaning are related to the values of the $\mathrm{K}=4$ explicative variables with $\beta_{k}$ representing the $\mathrm{k}$ unknown parameters to be estimated, while $\varepsilon_{t}$ representing the error term. 
The Augmented Dickey Fuller (ADF) statistics was used to examine the stationarity of the series and to understand whether the null hypothesis (existence of a unit root) or the alternative hypotheses (stationary process) can be considered valid in our study. The ADF results on the first-differences lead us to reject the null hypothesis, thus making model (1) with the HAC correction appropriate for a first exploration of the relationships among the studied variables.

\subsection{Empirical Results}

Table 1 reports the summary statistics of variables in our analysis. For each variable in the data set, the mean, three selected percentiles (P25-P50-P75), the standard deviation (SD) and the coefficient of variation (CV) are reported, therefore analysing both location and variability dimensions of the constructed data set.

Focusing on CV - as relative measure of variability - we observed high levels of variability, throughout the entire period of observation, for the variables related to the consolidated financial statement of the Eurosystem (i.e. Securities held for monetary policy purposes) and the Key ECB interest rates, with the ECB Deposit facility rate showing the highest $\mathrm{CV}$ value.

Table 1. Descriptive statistics of the variables included in the data set

\begin{tabular}{|c|c|c|c|c|c|c|c|}
\hline & VARIABLE & MEAN & P25 & P50 & P75 & SD & $\mathbf{C V}$ \\
\hline \multirow{4}{*}{$\begin{array}{l}\text { Banks balance sheet - } \\
\text { Deposits (stocks) }\end{array}$} & Households, overnight & 2398561.00 & 1734465.00 & 2234600.00 & 2949725.00 & 852460.10 & 0.36 \\
\hline & Households, total & 5697061.00 & 4612630.00 & 5823780.00 & 6496260.00 & 1107587.00 & 0.19 \\
\hline & Corporates, overnight & 1140586.00 & 836126.00 & 1007190.00 & 1495735.00 & 424714.50 & 0.37 \\
\hline & Corporates, total & 1700641.00 & 1359275.00 & 1653285.00 & 2082700.00 & 464484.40 & 0.27 \\
\hline \multirow{2}{*}{$\begin{array}{l}\text { Key } \\
\text { rates }\end{array}$} & $\begin{array}{l}\text { ECB Main refinancing } \\
\text { operations rate }\end{array}$ & 1.29 & 0.05 & 1.00 & 2.00 & 1.30 & 1.01 \\
\hline & $\begin{array}{l}\text { ECB Deposit facility } \\
\text { rate }\end{array}$ & 0.60 & -0.20 & 0.25 & 1.00 & 1.07 & 1.78 \\
\hline \multirow{3}{*}{$\begin{array}{l}\text { Consolidated } \\
\text { financial statement of } \\
\text { the Eurosystem } \\
\text { (expressed in million } \\
\text { Euros) }\end{array}$} & $\begin{array}{l}\text { Main refinancing } \\
\text { operations }\end{array}$ & 142125.90 & 58753.50 & 126491.80 & 220750.80 & 100327.50 & 0.71 \\
\hline & $\begin{array}{l}\text { Longer-term } \\
\text { refinancing } \\
\text { operations }\end{array}$ & 445066.20 & 144999.80 & 452198.00 & 692436.50 & 284637.80 & 0.64 \\
\hline & $\begin{array}{l}\text { Securities held for } \\
\text { monetary } \\
\text { policy purposes }\end{array}$ & 587023.70 & 0.00 & 137888.80 & 650110.30 & 907391.50 & 1.55 \\
\hline
\end{tabular}

Notes: Data are at monthly frequency covering the period Q1 2008-Q4 2019. Descriptive statistics refer to the values of the variables in absolute (original) terms.

The entire empirical distributions of the variables included in the data set are also shown by the box-plots reported in Figures 1a-1b-1c. The so-called "box and whiskers" plots, whose construction is in general based on 5 points of the empirical distribution (Min, P25, P50, P75, Max), are able to clearly show the variability of the entire distribution (through the Range visualization) of the central part of the distribution (through the Interquartile Range), as well as the presence of anomalous values (outliers) in the upper or lower part of the empirical distribution that modify the positioning of the extreme values (on the whiskers).

Focusing on Figure 1a and therefore on the Deposit variable group, we found a higher level of variability for the household deposits (overnight and total) than the corporate deposits.

On the other hand, a very low level of variability - both by analyzing the entire and the central part of the empirical distributions - was observed for the Main refinancing operations, while a number of upper outliers were found for the variable Securities held for monetary policy purposes. 


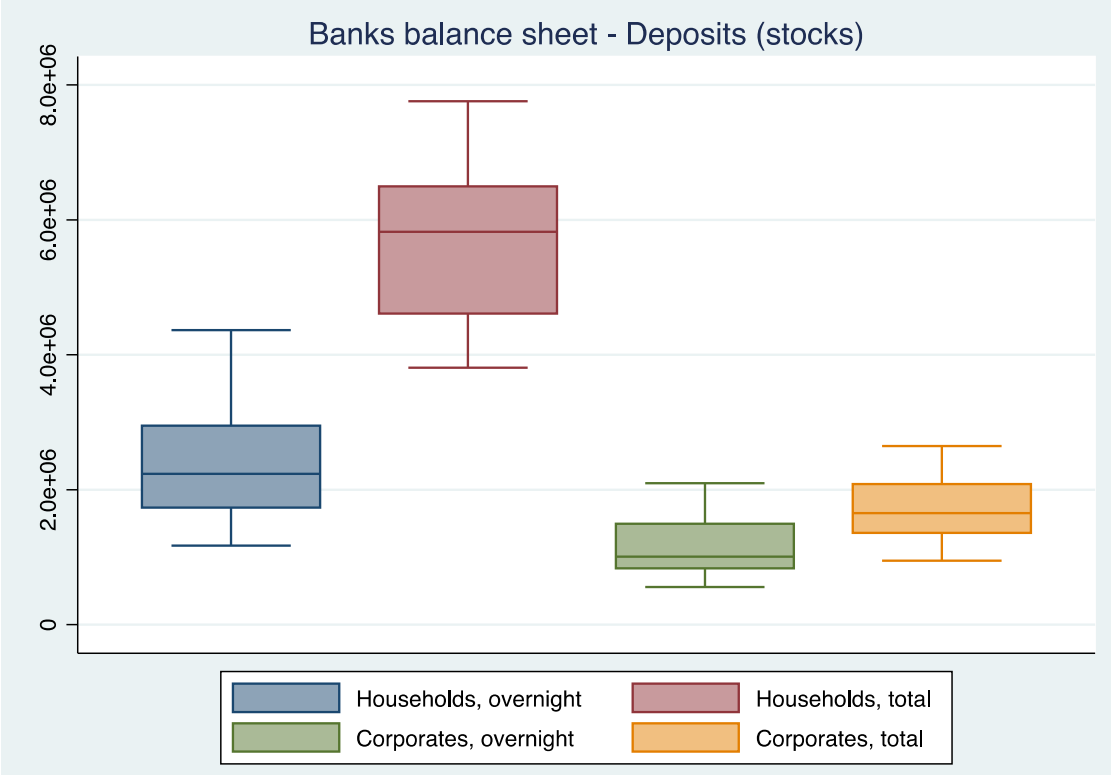

Figure 1a. Banks balance sheet - Deposits (stocks): box-plots

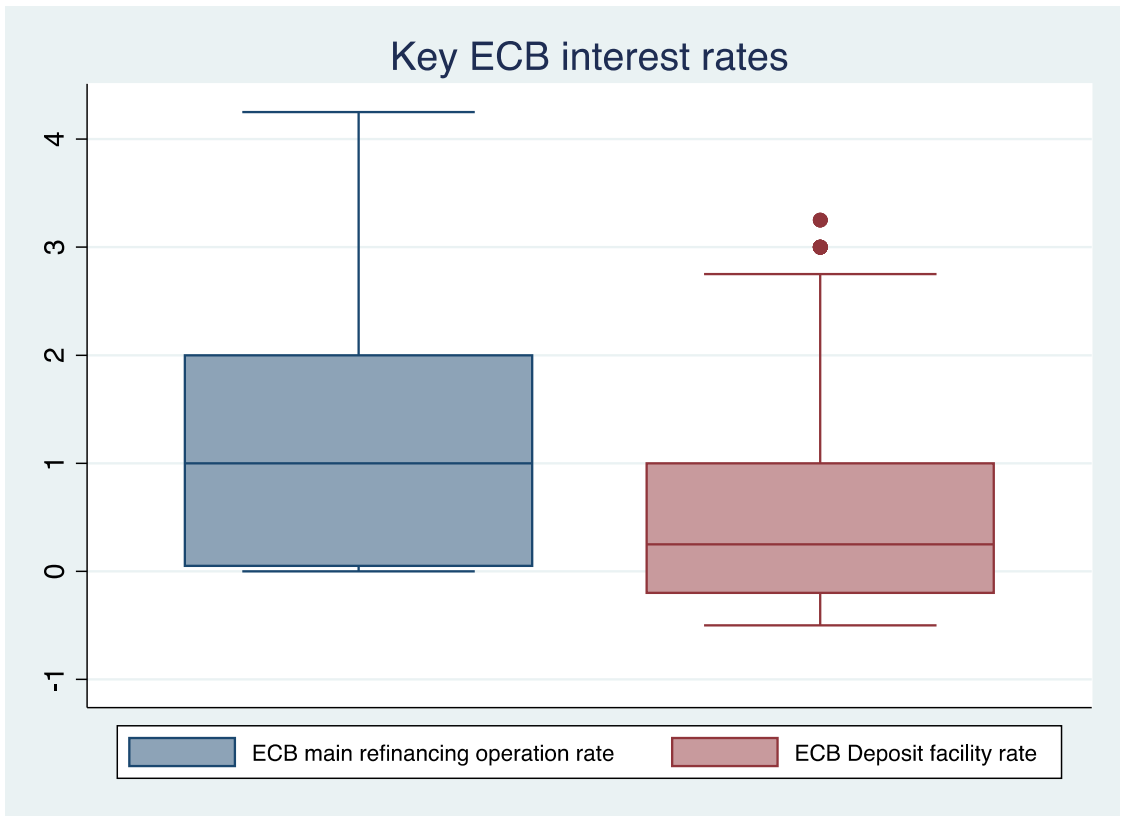

Figure 1b. Key ECB interest rates: box-plots 


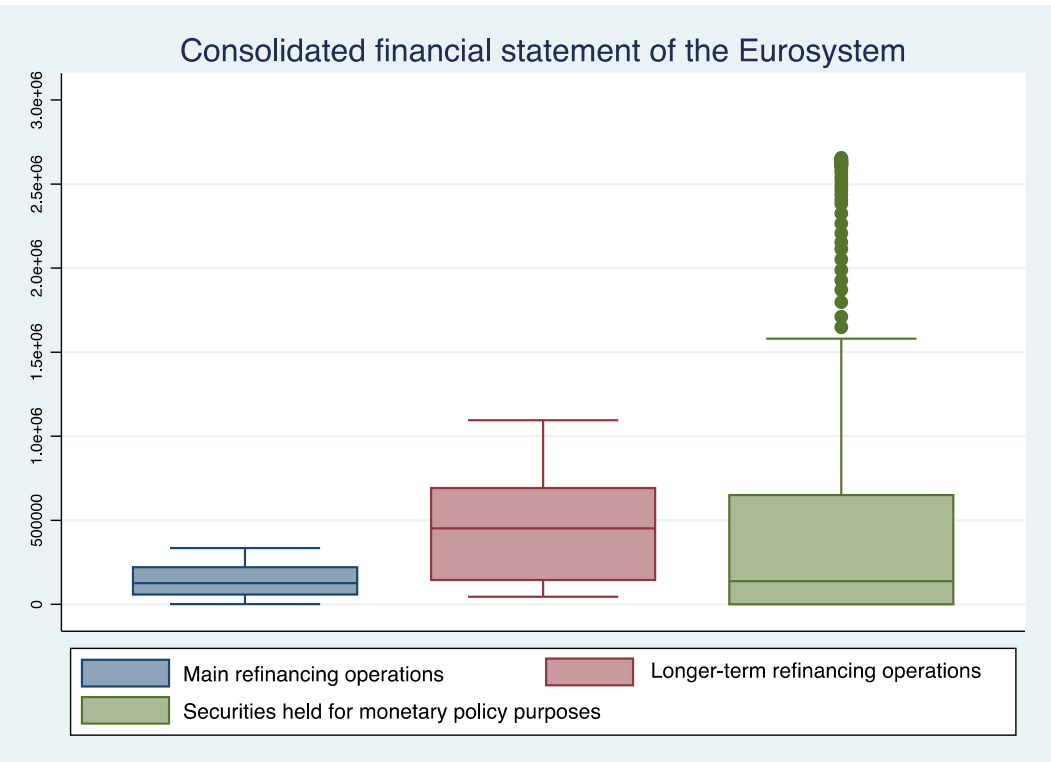

Figure 1c. Consolidated financial statement of the Eurosystem: box-plots

Table 2 reports the results of regression models on first-difference monthly values ( $\mathrm{N}=203$ values) of the four dependent variables describing stocks of deposits from euro area households and non-financial corporations (original observations from January 2008 to December 2019). Estimates were carried out by using the software STATA 14.2. We referred to the Newey and West (1987) estimator in order to obtain standard errors that account for (are robust to) heteroskedasticity and autocorrelation (Narayan et al., 2020).

Table 2. Newey-West regression analysis: estimation results for the four dependent variables

\begin{tabular}{|c|c|c|c|c|c|c|c|c|c|c|c|c|}
\hline & \multicolumn{3}{|c|}{ HOUSEHOLDS, OVERNIGHT } & \multicolumn{3}{|c|}{ HOUSEHOLDS, TOTAL } & \multicolumn{3}{|c|}{ CORPORATES, OVERNIGHT } & \multicolumn{3}{|c|}{ CORPORATES, TOTAL } \\
\hline & Coef. & HAC SE. & Sig. & Coef. & HAC SE. & Sig. & Coef. & HAC SE. & Sig. & Coef. & HAC SE. & Sig. \\
\hline $\begin{array}{l}\text { ECB Main refinancing } \\
\text { operations rate }\end{array}$ & 33816.440 & 23524.290 & & 27076.090 & 24015.720 & & 3066.326 & 29279.520 & & -794.681 & 20806.470 & \\
\hline ECB Deposit facility rate & -42364.260 & 22521.390 & $*$ & -42615.990 & 21105.730 & $* *$ & -3254.011 & 25524.160 & & 18950.210 & 17130.290 & \\
\hline Main refinancing operations & 0.163 & 0.093 & $*$ & 0.201 & 0.033 & $* *$ & 0.115 & 0.084 & & 0.101 & 0.080 & \\
\hline $\begin{array}{l}\text { Longer-term } \\
\text { operations }\end{array}$ & 0.090 & 0.029 & $* * *$ & 0.035 & 0.028 & & 0.050 & 0.029 & $*$ & 0.038 & 0.028 & \\
\hline $\begin{array}{l}\text { Securities held for monetary } \\
\text { policy purposes }\end{array}$ & -0.032 & 0.058 & & 0.205 & 0.046 & $* * *$ & 0.093 & 0.031 & $* * *$ & 0.046 & 0.030 & \\
\hline Constant & 19742.330 & 2153.196 & $* * *$ & 13040.600 & 2018.833 & $* * *$ & 6323.654 & 1238.756 & & 7939.312 & 1145.070 & $* * *$ \\
\hline
\end{tabular}

Notes: $* * *, * *$, and $*$ significant at the $1 \%, 5 \%$, and $10 \%$ levels. Dependent and explicative variables were introduced as first-differences according to the specification described in (1). Number of observations: 203.

The estimated coefficients together with the related statistical significance highlight a number of interesting results.

Firstly, we found a positive effect of a variation of Main refinancing operations on the monthly difference of Household total deposits and Household overnight deposits, with a greater level of significance for Household overnight stocks.

Secondly, the regression analysis highlights a significant negative relationship between ECB Deposit facility rate and Household deposits (both overnight and total). 
In addition, the empirical analysis shows a particularly solid positive relationship between Longer-term refinancing operations and Household overnight deposits, as well as a positive relationship, albeit less solid, between the same monetary policy variable and the stocks of Corporate overnight deposits.

It should be noted that the results summarized in Table 2 also show that the Securities held for monetary policy purposes are particularly effective in positively affecting both Household total deposits and Corporate overnight deposits.

On the other hand, with reference to the total deposits from euro area Corporates, there are no significant relationships with the monetary policy variables taken into consideration.

\section{Conclusions}

Recent research on the measures adopted by monetary authorities following the global financial crisis focuses on the relationship between UMPs and bank deposit rates.

Most of these research highlights the existence of a partial effect of UMPs on bank deposit rates as there is a minimum threshold for retail deposits. This threshold appears to exist as banks would be reluctant to apply negative rates on deposits, particularly with regard to deposits from households (Altavilla et al., 2019; Demiralp et al., 2019; Eisenschmidt and Smets, 2018).

Using "ECB Statistical Data Warehouse" as data source, with monthly historical series from 2008 to 2019, in this paper we analyze if UMPs implemented by the Eurosystem have had impacts on the stocks of banks' deposit from euro area households and non-financial corporations.

The results suggest some robust findings. In detail, we find that the UMPs adopted by the Eurosystem have had a significant positive correlation with euro area bank deposits (stocks), with particular reference to the relationship between Longer-term refinancing operations and Household overnight deposits, as well as between Securities held for monetary policy purposes and deposits from Households (total deposits) and from Corporates (overnight deposits).

UMPs have undoubtedly led to a high inflow of liquidity into the area euro banking system. We can therefore argue that this was reflected, inter alia, by an overall increase in bank deposits, with particular regard to Household deposits (both overnight and total) and Corporate overnight deposits.

The analysis considers the euro area banking system as a whole. Moreover, monetary variables are considered at an aggregate level (Eurosystem level), without distinguishing from country to country. However, the effects of UMPs on banks' deposit can be different across euro area banks and countries.

Therefore, in further study it would be interesting to investigate our research key within the individual countries of the euro area, perhaps subdividing them into vulnerable countries and less vulnerable countries.

\section{References}

Altavilla, C., Burlon, L., Giannetti, M., \& Holton, S. (2019, June). Is there a zero lower bound? The effects of negative policy rates on banks and firms. ECB Working Paper Series No. 2289. https://doi.org/10.2139/ssrn.3460947

Ballis, A., \& Drakos, K. (2020, March). Testing for herding in the cryptocurrency market. Finance Research Letters, 33, 101210. https://doi.org/10.1016/j.frl.2019.06.008

Bech, M., \& Malkhozov, A. (2016, March). How have central banks implemented negative policy rates?. BIS Quarterly Review, 31-44.

BIS. (2019). Unconventional monetary policy tools: a cross-country analysis. Report prepared by a Working Group chaired by Simon M Potter (Federal Reserve Bank of New York) and Frank Smets (European Central Bank). CGFS Papers No. 63, October.

Borio, C., \& Zabai, A. (2016, July). Unconventional monetary policies: a re-appraisal. Monetary and Economic Department. BIS Working Papers No. 570.

Brei, M., Borio, C., \& Gambacorta, L. (2019, August). Bank intermediation activity in a low interest rate environment. BIS Working Papers No. 807. https://doi.org/10.1111/ecno.12164

Claessens, S., Coleman, N., \& Donnelly, M. (2017, February). “Low-For-Long” Interest Rates and Banks' Interest Margins and Profitability: Cross-Country Evidence. International Finance Discussion Papers No. 1197. https://doi.org/10.17016/IFDP.2017.1197 
Demiralp, S., Eisenschmidt, J., \& Vlassopoulos, T. (2019, May). Negative interest rates, excess liquidity and retail deposits: banks' reaction to unconventional monetary policy in the euro area. ECB Working Paper Series No. 2283.

Diamond, D. W., \& Dybvig, P. H. (1983). Bank Runs, Deposit Insurance, and Liquidity. Journal of Political Economy, 91(3), 401-419. https://doi.org/10.1086/261155

ECB. (2016). Recent developments in the composition and cost of bank funding in the euro area. Economic Bulletin, (1), 26-42.

Eisenschmidt, J., \& Smets, F. (2018, March). Negative interest rates: Lessons from the Euro Area. Working paper.

Heider, F., Saidi, F., \& Schepens, G. (2018, August). Life below zero: bank lending under negative policy rates. ECB Working Paper Series No. 2173. https://doi.org/10.2139/ssrn.2788204

Ho, C. M., \& Lin, W. Y. (2020). Comparison of the Pass-through Speed Models of Different Markets: An Empirical Study of the Markets of Mainland China and Taiwan. International Journal of Banking and Finance, 15(1), 73-88. https://doi.org/10.32890/ijbf2020.15.1.9932

Hoechle, D. (2007, September). Robust standard errors for panel regressions with cross-sectional dependence. The Stata Journal, 7(3), 281-312. https://doi.org/10.1177/1536867X0700700301

Huang, R., \& Ratnovski, L. (2011). The dark side of bank wholesale funding. Journal of Financial Intermediation, 20(2), 248-263. https://doi.org/10.1016/j.jfi.2010.06.003

Kladívko, K., \& Österholm, P. (2020). Do market participants' forecasts of financial variables outperform the random-walk benchmark?. Finance Research Letters, 101712. https://doi.org/10.1016/j.frl.2020.101712

Narayan, P. K., Phan, D. H. B., \& Liu, G. (2020). COVID-19 lockdowns, stimulus packages, travel bans, and stock returns. Finance research letters, 101732. https://doi.org/10.1016/j.frl.2020.101732

Newey, W., \& West, K. (1987). A Simple, Positive Semi-Definite, Heteroskedasticity and Autocorrelation Consistent Covariance Matrix. Econometrica, 55(3), 703-708. https://doi.org/10.2307/1913610

Song, F., \& Thakor, A.V. (2007). Relationship Banking, Fragility, and the Asset-Liability Matching Problem. The Review of Financial Studies, 20(5), 2129-2177. https://doi.org/10.1093/rfs/hhm015

Stock, J. H., \& Watson, M. (2011). Introduction to Econometrics (3rd ed.). Boston. Pearson Education/Addison Wesley.

Stone, M., Fujita, K., \& Ishi, K. (2011, June). Should Unconventional Balance Sheet Policies be Added to the Central Bank Toolkit? A Review of the Experience So Far. IMF Working Paper, WP/11/145. https://doi.org/10.5089/9781455268467.001

Van Rixtel, A., \& Gasperini, G. (2013, March). Financial crises and bank funding: recent experience in the euro area. BIS Working Papers No. 406.

Yahaya, O. A., \& Onyabe, J. M. (2020). Firm Life Cycle and Financial Performance: Evidence from Nigeria. Journal of Accounting and Finance in Emerging Economies, 6(3), 723-732. https://doi.org/10.26710/jafee.v6i3.1332

\section{Notes}

Note 1. This paper does not consider the UMPs launched in 2020, in response to the COVID-19 pandemic, which are still ongoing.

Note 2. Diamond and Dybvig (1983) show that the deposit insurance is a determining factor also in preventing bank runs.

\section{Copyrights}

Copyright for this article is retained by the author(s), with first publication rights granted to the journal.

This is an open-access article distributed under the terms and conditions of the Creative Commons Attribution license (http://creativecommons.org/licenses/by/4.0/). 